\title{
La televisión ante el pasado reciente: ¿Cómo estudiar la relación entre TV y memoria social?
}

Claudia Feld

\begin{abstract}
Resumen: Este artículo propone indagar las maneras en que la televisión representa el pasado reciente de la Argentina, a través de tres articulaciones específicas entre TV y memoria social. Se sugieren tres abordajes, distintos en términos analíticos, para la investigación. Estos abordajes permiten enfocar el rol de este medio en la configuración de agendas públicas (o sea, se aborda a la televisión como emprendedora de la memoria), su efectividad como soporte para difundir acontecimientos del pasado entre las nuevas generaciones (es decir, como vebiculo de transmisión intergeneracional), o su rol como constructor de sentidos a través de imágenes, sonidos y palabras (es decir, la televisión se aborda como escenario de la memoria). Todos estos roles coexisten y se articulan, aunque también entran en tensión.

El artículo se centra particularmente en la experiencia del terrorismo de Estado en Argentina, en el marco de la dictadura militar de 1976-1983, y en las memorias construidas en torno a la desaparición forzada de personas. El análisis de los vínculos entre TV y memoria permite pensar de qué modos los obstáculos para narrar una experiencia límite se combinan, de maneras complejas y no fácilmente inteligibles, con la intención de vender un producto y de entretener al espectador.
\end{abstract}

Palabras Clave: Televisión. Memoria. Imagen. Dictadura. Represión.

\footnotetext{
* Investigadora Adjunta del Consejo Nacional de Investigaciones Científicas y Técnicas (CONICET), Argentina. Coordinadora Académica del Núcleo de Estudios sobre Memoria del IDES. E-mail: claudimages@yahoo.com.ar
} 
La última dictadura militar argentina se mantuvo en el poder entre 1976 y 1983. Aunque otros gobiernos militares la habían precedido, la represión que este régimen ejerció resultó inédita, tanto por su magnitud como por la principal modalidad que adoptó: la desaparición forzada de personas. Esta modalidad consistió en el secuestro, la tortura, la reclusión en prisiones clandestinas, seguidas del asesinato y la ocultación de los cuerpos de miles de opositores (CALVEIRO, 1998).

En los años que siguieron a la dictadura, el crimen de la desaparición produjo desafíos específicos para la memoria social y para la historia reciente en Argentina. Dentro de la problemática más general de la gestión de ese pasado, surgió el dilema de cómo representar esa experiencia límite ${ }^{1}$, en qué escenarios y espacios podían desplegarse esos relatos, qué lenguajes eran capaces y adecuados para transmitirlos.

Es claro que ni la memoria social ni la escritura de la historia se confrontaban por primera vez con dicha problemática. Muchos de estos interrogantes habían dado origen a debates y reflexiones en diversas sociedades, especialmente las que habían atravesado la experiencia de la Segunda Guerra Mundial y la Shoah. En muchas de estas discusiones, las preocupaciones centrales giraron en torno a los lenguajes apropiados para representar lo inimaginable por medio del arte; a los desafíos de la representación ligados a la narración histórica; o a las dificultades de quienes vivieron esa experiencia para narrar y dar testimonio sobre lo ocurrido ${ }^{2}$. Cuando esta preocupación se extendió hacia los medios audiovisuales, fue el cine, y especialmente al cine de ficción, lo que llamó la atención de muchos investigadores ${ }^{3}$.

El análisis del modo en que se representa una experiencia límite del pasado a través de relatos televisivos no ficcionales implica hacer ingresar a estas reflexiones nuevos marcos de análisis, incluir otros interrogantes y prestar atención a nuevas tensiones. La tensión entre una posible banalización de los lenguajes televisivos y una gran potencialidad de difusión del medio constituye, a la vez, un punto de interés central y una dificultad mayor a la hora de abordar una reflexión sobre el vínculo entre memoria social y televisión. De este tipo de análisis y de sus principales dilemas se ocupará este artículo. 


\section{Claudia Feld}

\section{La memoria como objeto de estudio}

En los últimos años, tanto en Argentina como en otros países del Cono Sur de América Latina, muchas investigaciones han tomado a la memoria como objeto para hacer de ella un centro de gravedad en el estudio del pasado reciente. Estos trabajos presentaron importantes avances para reconstruir procesos políticos y sociales ocurridos durante las décadas del '70 y del ' 80 en la región, estudiando las luchas por interpretar y redefinir sentidos acerca de esos períodos del pasado, y situando actores e instituciones involucrados en la tarea de recordar y hacer recordar a otros/as las experiencias de sufrimiento y violencia vividas entonces. Más allá de la variedad de temáticas y abordajes que presentan estas investigaciones, podría decirse que el campo de los estudios sobre memoria constituye un fructífero terreno de debates desde el que se construyen categorías, se realizan innovaciones metodológicas y se crean lazos entre las diversas disciplinas; $y$ esta actividad académica también tiene efectos de diverso alcance en las discusiones éticas y políticas acerca del pasado reciente y en la configuración de políticas públicas de memoria ${ }^{4}$.

Dicho campo de estudios reconoce, entre otras muchas influencias, las que provienen de una sociología de la memoria, desde los trabajos pioneros de Maurice Halbwachs (2004 [1950]) hasta las investigaciones de Michael Pollak (1990 y 1993) sobre el recuerdo de las experiencias límite; las influencias de una historia de la memoria, que se reconoce fundamentalmente en las investigaciones realizadas en Francia por Pierre Nora (1984-1992) y Henry Rousso (1987), entre otros historiadores; y las de una filosofía de la memoria que analiza la dialéctica entre memoria y olvido, el estatuto del recuerdo, las características de la conciencia histórica, las "figuras de la memoria herida" (RICOEUR, 2000) y los dilemas ligados a los "abusos" y "excesos" de la memoria (TODOROV, 1995). Hay también una línea de trabajos centrados en la noción de "trauma", con investigaciones realizadas tanto por psicoanalistas, como por historiadores y cientistas sociales (CARUTH, 1996; LACAPRA, 2009, entre otros).

Desde mediados de los años ' 90 , principalmente, estos trabajos son releídos en el Cono Sur y dan lugar a numerosas investigaciones sobre la memoria social en las que confluyen estos distintos abordajes. En el campo de debates e investigaciones argentino, esta temática es 
retomada en un contexto específico regional en el que los estudios sobre memoria buscan, por una parte, ayudar a gestionar y elaborar experiencias traumáticas o dolorosas ligadas a las situaciones de violencia y represión dictatorial; y, por otra, abordar la etapa de transición democrática, intentando diferenciar el presente "democrático" del pasado "autoritario". En este marco, las investigaciones sobre memoria no apuntan solamente a reconstruir la historia de aquellos años, sino - como afirma Elizabeth Jelin - a "analizar el proceso social de rememorar (y de olvidar), estudiando los diversos niveles en los cuales se da" (JELIN, 2002, p. 2). Por lo tanto, investigar sobre memoria implica "pensar y analizar las presencias y sentidos del pasado en nuestras sociedades", examinando "las marcas simbólicas y materiales en las cuales se anclan estos procesos de rememoración" (JELIN, 2002, p. 2).

El presente artículo se inserta en este campo de trabajo pero con un eje particular, el de analizar el vínculo entre memoria y televisión, proponiéndolo como un terreno de exploración específico para abordar una serie de fenómenos, que tanto desde las investigaciones sobre historia reciente como desde los estudios sobre memoria social deberían ser tenidos en cuenta. Quisiera sugerir tres abordajes, es decir, tres maneras posibles de entender a la televisión como objeto de indagaciones e investigar este vínculo. Estos abordajes no son los únicos posibles ni se excluyen entre sí. Sin embargo, elegir uno u otro implica enfocar fenómenos diversos y, por lo tanto, construir objetos de investigación y dispositivos metodológicos diferentes.

\section{Primer abordaje: la televisión como emprendedora de la memoria}

A partir de un acontecimiento televisivo ocurrido en la Argentina a mediados de los años ' 90 y de sus repercusiones mediáticas y extramediáticas, que se extienden hasta hoy, quisiera explorar estos tres posibles abordajes en la investigación del vínculo entre televisión y memoria social.

En 1995, existía una situación de impunidad para los represores que habían secuestrado, torturado y hecho desaparecer a miles de personas en Argentina. Después de las leyes de "Punto Final" 


\section{Claudia Feld}

(1986) y “Obediencia Debida" (1987), y luego de los indultos a los responsables procesados y juzgados (1989 y 1990), parecía que la cuestión de los desaparecidos no interesaba más que a los actores directamente involucrados. Los medios de comunicación habían dejado de tratar el tema, no se producían grandes eventos públicos y solo los sobrevivientes, los organismos de derechos humanos y los familiares de desaparecidos seguían trabajando para hacer oír sus denuncias y sus reclamos de verdad y de justicia.

Sin embargo, en marzo de 1995, un acontecimiento aparentemente menor llevó nuevamente el tema al espacio público y le dio centralidad en los medios de comunicación. Se trató de la declaración del ex capitán de la Marina Adolfo Francisco Scilingo que había trabajado, durante la dictadura, en la Escuela de Mecánica de la Armada (ESMA) ${ }^{5}$. En un programa periodístico de televisión ${ }^{6}$, Scilingo relató su participación en los operativos que se hacían para arrojar al mar a detenidos-desaparecidos vivos, desde aviones en vuelo ${ }^{7}$. En ese marco, dijo que él mismo había matado a treinta personas:

"Participé en dos traslados aéreos, el primero con 13 subversivos a bordo de un Skyvan de la Prefectura, y el otro con 17 terroristas en un Electra de la Aviación Naval. Se les dijo que serían evacuados a un penal del sur y por ello debían ser vacunados. Recibieron una primera dosis de anestesia, la que sería reforzada por otra mayor en vuelo. Finalmente en ambos casos fueron arrojados desnudos a aguas del Atlántico Sur desde los aviones en vuelo." (Declaraciones de Scilingo en el programa Hora Clave, 9 de marzo de 1995)

Aunque en los años anteriores se habían producido ya varias declaraciones públicas de militares con respecto a los crímenes cometidos por la dictadura, esta era la primera vez que un represor narraba lo que él mismo había hecho, sin negarlo ni encubrirlo con eufemismos, y daba detalles sobre el sistema de eliminación de secuestrados denominado "vuelos de la muerte". Esto sucedía, además, ante las cámaras de televisión. El protagonista de los hechos miraba de frente a la cámara y sellaba, de esa manera, un pacto de veracidad con el público. En el lenguaje de la televisión, la mirada hacia la cámara genera un contacto privilegiado con el espectador, en el que quien habla parece mirarlo a los ojos. De esta manera, opera como índice de "desficcionalización", creando el efecto de sentido de que el enunciador se refiere efectivamente a la "realidad" y otorgando "una 
especie de 'prueba' del anclaje del discurso en lo real de la actualidad" (VERÓN, 1983, p. 105).

Las informaciones que dio Scilingo no satisficieron las demandas de conocer la verdad sobre la represión clandestina que desde hacía tiempo esgrimían las organizaciones de derechos humanos. No sirvieron para saber qué pasó con cada desaparecido ni quiénes fueron los demás responsables de tales crímenes. Sin embargo, las repercusiones de los dichos de Scilingo fueron inmediatas: enseguida, otros programas de TV buscaron a represores desconocidos tratando de lograr, no siempre con éxito, que hicieran sus "confesiones" frente a las cámaras (FELD, 2009b). El tema de la represión dictatorial se instaló en los diversos medios de comunicación, como una temática ineludible, en la que primó la idea de que se trataba de crímenes impunes, con víctimas, victimarios y una violencia oculta que debía sacarse a la luz.

Las declaraciones de Scilingo, hechas al amparo de la impunidad y conjugadas poderosamente con los lenguajes televisivos, tuvieron también consecuencias que excedieron el ámbito de los medios de comunicación: generaron nuevas posibilidades en la Justicia (como los Juicios por la Verdad), alentaron la acción de nuevos actores (como la agrupación H.I.J.O.S.), contribuyeron a emplazar nuevos sitios de recordación (la costa del Río de la Plata en la ciudad de Buenos Aires, por ejemplo) ${ }^{8}$. La conmemoración del golpe de Estado, unas semanas más tarde, consiguió un impulso y una masividad que hacía tiempo no tenía?.

En abril de 1996, el juez Baltasar Garzón inició el procesamiento de algunos militares argentinos que actuaron durante la última dictadura militar. Si bien Scilingo estaba protegido en Argentina por la ley de "Obediencia debida", quedó detenido en Madrid en 1997 y, como parte de ese proceso, la justicia española lo condenó a 640 años de prisión por delitos de lesa humanidad, secuestro y torturas. Esto sucedió en abril de 2005, diez años después de sus primeras declaraciones públicas ${ }^{10}$.

Este breve recorrido da una idea de la complejidad del trabajo de la memoria y de las maneras imprevisibles en que se dan los procesos de recuerdo y acción con respecto al pasado en sociedades que han atravesado experiencias límite. Las declaraciones televisivas de Scilingo no respondieron de manera inmediata a las expectativas 


\section{Claudia Feld}

de verdad y justicia que generaron. De algún modo parecía que afianzaban la impunidad de este represor y que incluso la exhibían espectacularmente. Sin embargo, en una dinámica que excede lo planteado aquí, y a través de distintos actores y momentos políticos, estas declaraciones televisivas contribuyeron a abrir una "ventana de oportunidad" para que pudieran avanzar con sus demandas las organizaciones de derechos humanos que luchaban en Argentina desde hacía muchos años.

Este es un primer vínculo que quisiera mencionar entre televisión y memoria: en determinados contextos políticos e históricos, la televisión puede favorecer los denominados procesos de "salida de olvido" de un período conflictivo del pasado que se mantiene en silencio.

Este caso no ha sido el único. Es sabido que cuando fue emitida en Alemania la serie norteamericana Holocausto ${ }^{11}$, provocó una apertura del debate sobre el pasado Nazi, sobre los grados de complicidad del pueblo alemán en el exterminio y alentó una revisión del tema por parte de las nuevas generaciones crecidas en los años de silencio (BAER, 2006, p. 120-122).

En Estados Unidos, la televisación del juicio a Adolf Eichmann, mientras se estaba desarrollando en Israel, en 1961, contribuyó a instalar "la noción de Holocausto como un paradigma intelectual y ético en la cultura pública norteamericana” (SCHANDLER, 1999, p. 107).

Pero en el caso de Scilingo, no se trataba ni de una reconstrucción ficcional de los hechos ni de la televisación de un suceso que ocurría en el ámbito judicial. El acontecimiento se había producido en un estudio televisivo como parte de la construcción de actualidad realizada por este medio, y se lo postulaba - además - como una revelación. En tanto medio que conjuga el alcance masivo, la simultaneidad en la recepción, la instantaneidad de la difusión y diversas expectativas de verdad construidas a partir de una articulación específica entre palabra e imagen, la televisión permitió transformar el discurso de Scilingo en acontecimiento social y político.

Colaboraron, en todo el proceso, las acciones de otros "emprendedores de la memoria" ". Pero, en ese marco, la televisión como institución ${ }^{13}$ también asumió el rol de emprendedora de la memoria y, a partir de 1995, muchos periodistas y productores de distinto signo ideológico y diferentes estilos comunicacionales tomaron la iniciativa de abordar el tema del terrorismo de Estado, proponiéndose generar 
acontecimientos, novedades y acciones sobre la memoria. Lo hicieron, en realidad, con objetivos diversos, entre los que se mezclaban una particular concepción del deber de memoria, el afán de no quedarse afuera de la "agenda" periodística, y la intención de hacer subir el rating con un tema que se sospechaba de interés para el gran público.

Lo que importa, en este caso, es analizar las maneras en que la televisión actúa como campo de lucha entre memorias, y el modo en que se cristalizan en el espacio televisivo las diversas disputas alrededor del pasado. Así, este abordaje pone el foco en las luchas por la memoria, considerándola como objeto de "disputas, conflictos y luchas, lo cual apunta a prestar atención al rol activo y productor de sentido de los participantes de esas luchas, enmarcados en relaciones de poder" (JELIN, 2002, p. 2).

\section{Segundo abordaje: la televisión como escenario de la memoria}

El trabajo de la memoria no solo requiere de actores, es decir, de personas o instituciones encargadas de elaborar el recuerdo y construir representaciones sobre el pasado y llevar al espacio público sus emprendimientos memoriales. Necesita, además, espacios o escenarios en donde una "presentación de" y un "discurso sobre" el pasado sean posibles. Estos escenarios tienen sus reglas y lenguajes específicos, que determinan, a su vez, la producción de los relatos.

La televisión es uno de esos escenarios de la memoria y este es el segundo tipo de articulación entre televisión y memoria que quisiera sugerir. Llamo escenario de la memoria al espacio en el que se hace ver y oír, a un determinado público, un relato "veritativo" sobre el pasado. La noción de "escenario de la memoria" implica subrayar dos características del trabajo de la memoria. Primero, la voluntad de generar un tránsito entre un pasado que se da por finalizado y un presente que se interpreta como diferente del pasado (RICOEUR, 1999). Segundo, la "pretensión veritativa" de la memoria: tal como plantea Ricoeur, en su trabajo de hacer presente algo ausente, el trabajo de la memoria, a diferencia de la imaginación, tiene como objeto la exactitud y la fidelidad, más allá de que lo logre o no (RICOEUR, 
1999, p. 29). Esto hace necesario un proceso de construcción y de legitimación de una verdad sobre lo sucedido.

La idea de "escenario" - a diferencia de otras categorías como "lugares de memoria" (NORA, 1984), o "vectores del recuerdo" (ROUSSO, 1987) - permite enfocar más claramente problemas relacionados con la puesta en escena, la tensión dramática, los dispositivos narrativos puestos al servicio de la construcción de sentidos sobre el pasado, y los mecanismos por los cuales se seleccionan, jerarquizan y reúnen diversas voces o testimonios. Por lo tanto, además de indagar en el rol de la televisión como "emprendedora de la memoria", pueden analizarse los programas televisivos mismos, en sus formatos y lenguajes ${ }^{14}$.

Como se ha dicho, los interrogantes sobre cómo y con qué lenguajes narrar una experiencia límite han dado origen a debates y reflexiones en diversas sociedades, muchos de ellos referidos a la Segunda Guerra Mundial y la Shoah. Con relación a los medios audiovisuales, esos debates incorporaron al menos tres dilemas principales que me gustaría señalar.

- Un primer dilema de orden expresivo, acerca del lenguaje adecuado para representar lo sucedido o, en otras palabras, los límites del lenguaje para representar lo que se concibe como "inimaginable", "irrepresentable" etc. ${ }^{15}$

- Un segundo dilema de orden ético, acerca de cómo no profanar la memoria del acontecimiento, cómo no trivializarlo, cómo no prolongar el horror a través de su representación por medio de imágenes, entre otras cuestiones.

- Finalmente, un dilema de orden político, que se centra en las oportunidades y momentos políticos, y en las consecuencias políticas de determinadas representaciones que acceden al espacio público ${ }^{16}$.

Algunos de estos dilemas de la representación de una experiencia límite entran en tensión con las lógicas dominantes de la comunicación televisiva, aquellas que se ponen en juego para que algo ingrese o no a la televisión ${ }^{17}$. ¿Cuáles son esas lógicas? La lógica espectacular, que suele establecer formatos y lenguajes altamente convencionalizados para los programas televisivos; la lógica comercial, que lleva a poner en la pantalla chica lo que se considera susceptible de hacer subir el rating; y la lógica de captación de audiencia, que propone reunir a la mayor cantidad posible de público ante un 
mismo programa: al espectador joven y al experimentado, al que conoce lo que sucedió y al que no tiene información, al comprometido y al indiferente.

Es verdad que estas tres lógicas puestas en funcionamiento podrían transformar la memoria de una experiencia límite en espectáculo, en producto para la venta masiva, y en relato abarcador y digerible para todos. Pero es cierto también que estas mismas lógicas garantizan que un tema será mostrado por la televisión y visto por un amplio público.

Del estudio sobre programas de géneros informativos (especialmente, programas periodísticos de opinión y documentales) emitidos por la televisión abierta argentina entre 1995 y 2000 ${ }^{18}$, es decir, de los cinco años posteriores a las declaraciones de Scilingo, se desprende la observación de que, en general, estos relatos televisivos parecen ocluir los aspectos no espectaculares de los hechos narrados, privilegian el drama por sobre la comprensión histórica, y buscan un impacto emocional más que una toma de conciencia política acerca de lo sucedido.

El carácter efímero de las imágenes televisivas, que se debe al hecho de que en el flujo televisivo toda imagen nueva tiende a borrar o hacer invisible a la anterior ${ }^{19}$, es compensado por la reiteración constante de unas pocas imágenes "cliché" que terminan por convertirse en emblemas fácilmente reconocibles. Son imágenes que no se utilizan para señalar un referente específico, sino que sirven para entrar "en tema". Condensan y simbolizan diversos acontecimientos, simplificando a veces procesos históricos complejos.

Por ejemplo, en este caso, la imagen del frente de la Escuela de Mecánica de la Armada (ESMA) se utiliza para evocar cualquiera de los centros clandestinos de detención que funcionaron en todo el país, simbolizando la noción misma de centro clandestino y la experiencia del cautiverio. Los rostros de algunos militares muy conocidos - como Emilio Massera, Jorge Rafael Videla o Alfredo Astiz - condensan la categoría general de "represores" y operan como íconos intercambiables sin que se incluya una explicación acerca de la responsabilidad concreta de cada uno de ellos.

Son imágenes que pueden fijar una memoria, volverla de algún modo "estable" y hacerla accesible a un público masivo. Al mismo tiempo que logran transmitir exitosamente ese relato, tienden a 
fracasar a la hora de dar una versión compleja de la historia, abrir interrogantes, proponer líneas de acción para el futuro y politizar la vinculación con los hechos del pasado.

En definitiva, el análisis de estos programas televisivos y el abordaje de la televisión como escenario de la memoria nos permiten reflexionar sobre la relación y la tensión entre imagen y verdad histórica, y entre memoria y espectáculo, y pensar de qué modo el deber de memoria y los obstáculos para narrar una experiencia límite terminan combinándose, de maneras complejas y no siempre evidentes, con la intención de vender un producto y de entretener al espectador.

\section{Tercer abjordaje: la televisión como vehículo de transmisión intergeneracional}

El tercer y último eje que quisiera señalar en la indagación del vínculo entre memoria y televisión es el del rol que cumple este medio en el trabajo de transmisión hacia las nuevas generaciones. Es evidente que la televisión es un vehiculo de transmisión entre muchos otros: la educación formal, el ámbito familiar, otros consumos culturales, las redes sociales, los diversos espacios culturales específicamente juveniles, etcétera. Un abordaje de este tipo debería, por ende, observar tanto la diferencia como la interacción entre todos esos ámbitos y soportes. En ese marco, la televisión presenta ciertas características específicas: la inmediatez, la facilidad de lectura, el potencial emotivo, el alcance masivo, el consumo doméstico, la fuerte penetración en todos los estratos sociales y el impacto sobre los jóvenes.

Durante el año 2000, realicé entrevistas en profundidad a una cantidad reducida de jóvenes de la ciudad de Buenos Aires nacidos entre 1976 y 1979, es decir, durante los primeros tres años de la dictadura militar. Se trataba de estudiantes de diferentes carreras universitarias y terciarias, con diversas extracciones sociales e historias familiares. Ninguno había sido víctima directa de la represión ni era pariente de desaparecidos, y ninguno pertenecía a una familia de militares. Al momento de la entrevista tenían entre 21 y 24 años y, por su edad, no poseían recuerdos propios de lo sucedido durante la dictadura, de manera que su "memoria" conjugaba recuerdos de lo que les 
fue transmitido a través de diversas vías y en distintos momentos de su curso de vida, con las apreciaciones sobre lo sucedido que ellos mismos habían desarrollado ya como adultos. Estos jóvenes llegaron a la mayoría de edad alrededor de 1995, en el momento en que el tema de la represión dictatorial se reabría al espacio público a partir de las declaraciones de Scilingo ${ }^{20}$.

Si bien estos entrevistados no configuran una muestra representativa y, por ende, las entrevistas no pueden darnos datos concluyentes acerca del rol de la televisión en el trabajo de transmisión, sí alcanzan a ofrecer algunas pistas que me gustaría presentar.

Por las maneras en que construían sus relatos sobre la dictadura y por los elementos que traían en sus evocaciones, puede pensarse que la televisión les había ofrecido a estos jóvenes claves narrativas sobre cómo interpretar la historia (recordemos que en esa época la temática había estado fuertemente presente en el espacio televisivo en los cinco años anteriores a las entrevistas). Eran claves que les permitían acercar lo sucedido en el pasado a su propia experiencia, aunque no siempre sus relatos coincidían con la verdad histórica.

Los relatos de los entrevistados se basaban en la despolitización de los desaparecidos, la idea de que la desaparición había sido un fenómeno masivo que podía sucederle a cualquiera y la convicción de que a muchos se los habían llevado solo porque sus nombres estaban en una agenda (la mención a la "agenda" se repite constantemente). Algunos entrevistados evocaron el miedo que se sentía en aquel momento, pero sin tener una explicación concreta acerca de quiénes sentían miedo y por qué. En general, si se referían a la acción de las personas que desaparecieron, lo hacían diciendo que tenían ideas diferentes o que se oponían a la dictadura:

En esas épocas estaba todo tan inseguro que no se podía salir ni a la esquina, algo así, sacabas la cabeza por la ventana y te sacaban, te llevaban de tu casa. Eran momentos muy tensos. $\left(\right.$ Darío $\left.^{21}\right)$

Los desaparecidos son los que se animaron por un lado a expresar esas ideas diferentes, o los que[...], o sea, sin animarse, trataban de hacer lo posible porque esas ideas lleguen a la 
gente [...]. Los desaparecidos quizás son[...], alguna gente que estuvo en un lugar incorrecto, en un momento incorrecto. (Ramiro)

Pertenecían a un partido político o idea política diferente a la que tenían ellos[...], o el simple hecho de en algún lugar estar puesto tu nombre y esté conectado con alguna persona que sabían que estaba teniendo cierta ideología, entonces, por el hecho de aparecer en una agenda telefónica, sonabas. (Maximiliano)

No sé, aparte lo que quizás más repugnancia da es que era gente que estudiaba o que no estaba de acuerdo, es una cosa que hoy en día es, qué loco, cómo puede ser que alguien porque piense distinto, le hagan tantas cosas. (Nicolás)

La concepción de que "podría haberle sucedido a cualquiera" favorecía, en primer lugar, la identificación con las víctimas. Los/as entrevistados/as dicen, por ejemplo, que desaparecían jóvenes de su edad, que pensaban como podrían haber pensado ellos, etcétera.

En un contexto de despolitización y desprestigio de la acción política, como fueron los años '90 en Argentina, esta clave narrativa también era funcional a la noción de que la política era peligrosa y de que, en todo caso, la militancia no implicaba otra acción que "pensar distinto". Cualquier idea de compromiso político, de activismo social o incluso de transformación de la sociedad a través de la política, quedaba así desterrada del imaginario vinculado a la represión de los años '70.

Es necesario aclarar que estas ideas estaban muy instaladas en el sentido común argentino en el momento de las entrevistas, y que se habían difundido durante años a través de diversas producciones culturales y discursos públicos ${ }^{22}$. Pero también vertebraban la mayoría de los relatos televisivos, especialmente aquellos programas que los entrevistados/as relataban haber visto.

La televisión también les había ofrecido elementos para gestionar sus emociones frente a estos hechos. La mayoría de los relatos contenidos en estas entrevistas responden a una clave emocional muy común en los programas de entonces: conmoción, indignación, 
impotencia, son algunos de los sentimientos que se evocan en las entrevistas en relación con la temática de los desaparecidos. Sin embargo, no siempre esos sentimientos están acompañados con una información sobre lo que los provoca. Es llamativa la distancia entre lo que sienten (o dicen sentir) y lo que saben (o dicen saber). Ellos/as mismos mencionan la falta de información y dicen tener "una nebulosa" o mucha vaguedad en lo que refiere a la historia:

Me sigue provocando horror todo eso, pero hoy en día creo que necesito esclarecer toda esa nebulosa que tengo, separar bien todos esos nombres y lugares comunes que tengo en la cabeza, pero que no puedo, no, no puedo clasificarlos adecuadamente; tengo nombres pero no tengo cargos, no tengo hechos claros, ¿ंentendés?, tengo cosas así sueltas y sí mucha indignación e impotencia. (Abel, el enfatizado es mío).

Pero la televisión ha servido también como disparador del recuerdo, sobre todo en los casos en que miraron los programas con sus padres o con otros adultos. Si en muchas ocasiones hablan de historias que ocurrieron "al lado" de ellos o que "podrían haberle pasado a cualquiera”, pero no dan mucha precisión sobre casos específicos, es al hablar de algunos programas y de la conversación que tuvieron con adultos al momento de verlos, cuando comienzan a surgir recuerdos sobre personas e historias concretas.

Esto sucedió, por ejemplo, con uno de los entrevistados en el segundo encuentro, en el que se incluyó la visualización de un programa televisivo previamente grabado:

¿Qué cosas son las que más te impactan (en el programa visualizado), o en qué sentido te impactan?

Los testimonios de los detenidos y de los hijos [...] No sé, me pega muchísimo, porque [...] porque bueno esos chicos tienen mi edad, o andan por ahí, y [...] qué se yo, se han llevado gente también, [...] de la edad de mi mamá[...] bueno, también, no sé, mirá, uno de los testimonios me hace acordar mucho al caso de un señor que fue hace poco a $[\ldots]$, 


\section{Claudia Feld}

mi vieja es peluquera, se fue a cortar el pelo, justo estaba yo, y contó que a él lo chuparon, y que lo torturaron $[. .$.$] y [...]$ me pegó muchísimo, y ahora me hizo acordar a eso, uno de estos casos, porque el tipo se parecía." (Abel)

Finalmente, los programas de televisión (y también algunas películas de cine estrenadas en esa época ${ }^{23}$ ) les ofrecieron imágenes con las que ilustrar esos hechos y volverlos "visibles" y "tangibles". En las referencias que ellos/as hacen a tales imágenes, las escenas reconstituidas por los programas televisivos se confunden a veces con imágenes fílmicas de archivo y lo que "se ve" se menciona como algo que realmente sucedió, como imágenes que pertenecen al pasado.

Por ejemplo, cuando surgieron las primeras declaraciones de Scilingo muchos noticieros televisivos las acompañaron con filmaciones de aviones militares en vuelo, que evidentemente - al tratarse de crímenes secretos y clandestinos - no eran imágenes de archivo, sino que recreaban o simplemente ilustraban los llamados "vuelos de la muerte"24. En las entrevistas, esas mismas imágenes eran evocadas por estos/as jóvenes como si hubieran visto a través de ellas lo que "realmente" pasó en la dictadura. Dicen: "vi los aviones", "muestran los aviones".

Sí, yo no sé si en la tele, yo no tengo un recuerdo así fijo de la primera vez que escuché, pero [...] pero sí sé que no fue algo que me vinieron a decir específicamente; yo sé que por algún lado me enteré y pregunté yo a mis papás, qué fue, o sea, qué fue el golpe de Estado. Tampoco tengo mucha idea al respecto, o sea, sé más o menos. Este [...] bueno, y [...] qué eran los desaparecidos, y los últimos tiempos sí vi un montón en televisión que mostraban los aviones, o sea, que sé eso, sí. Pero [...] pero no tengo mucho recuerdo [...]. (Mariela)

En el video se muestran imágenes, mientras están en el Juicio, muestran imágenes que pasaron en la dictadura y cuando hablan del traslado o de que se van para arriba, muestran imágenes de los aviones". (Carolina, el enfatizado es mío) 
Además, las imágenes que caracterizamos como “emblemáticas" en el análisis de los programas, aparecen repetidamente en el relato de estos/as jóvenes. Por ejemplo, cuando se refieren a los represores, nombran a las dos o tres personas cuyos rostros suelen aparecer como "imágenes cliché" en la televisión, sin hacer diferenciaciones entre ellos ni dar precisiones sobre sus distintas responsabilidades en el marco de la dictadura.

Videla, Massera, todos más o menos lo mismo, sí, todos parte del tema ese y bueno, todos involucrados con el tema de los desaparecidos, todos en la misma bolsa. (Mariela)

Creo que Astiz era de Naval, creo que Massera, supongo era de los militares [...] y no sé si Videla también era de los militares, sé que Videla era como que tenía un rango más que todos, es el Videla que tengo, fue uno, digamos, de los iniciadores y proclamadores y dirigentes de todo el Proceso y lo único que te puedo decir". (Maximiliano)

Es evidente que la recepción televisiva se entrelaza con la de muchos otros productos culturales y medios de transmisión de memorias. También es evidente, por eso mismo, que no puede precisarse con cuál de estos medios se vincula cada recuerdo. Además, es sabido que los relatos televisivos se han configurado con claves narrativas que antes pertenecían al sentido común o a ciertos relatos hegemónicos instalados por otros productos culturales y discursos públicos. Aun así, es claro que, en la etapa que estamos analizando, la televisión ha ayudado a acercar las referencias del pasado a un público joven, a hacer la historia "visible" y a generar emociones más vívidas con respecto a lo sucedido.

En suma, el espacio televisivo ha colaborado en la creación de un público interesado. Sin embargo, ese interés se parece más a una preocupación general por la temática o un involucramiento desde lo emocional, que a un envolvimiento intelectual o incluso político, es decir, a un tipo de interés que podría llevar a la acción. En este aspecto, cabe preguntarse hasta qué punto estos vehículos de transmisión permiten que la experiencia histórica se articule con 
la experiencia presente. Tal como lo plantea Andreas Huyssen, con respecto a la memoria del Holocausto: "El porvenir no habrá de juzgarnos por olvidar, sino por recordarlo todo y, aun así, no actuar en concordancia con esos recuerdos" (HUYSSEN, 2002, p. 164).

\section{A modo de conclusión}

La construcción de un vínculo entre memoria y televisión permite abrir un amplio campo de exploración para estudiar una serie de fenómenos diversos. Se pueden aplicar distintos abordajes, según se quiera subrayar el rol de este medio de comunicación en la configuración de agendas públicas (como emprendedor de la memoria), o su efectividad como soporte para difundir acontecimientos del pasado entre las nuevas generaciones (como vehículo de transmisión), o su rol como constructor de sentidos a través de imágenes, sonidos y palabras (como escenario de la memoria). Todos estos roles, por supuesto, coexisten y se articulan de maneras que deberán ser exploradas más exhaustivamente.

Quisiera concluir entonces marcando algunas tensiones que emergen de la articulación entre estos tres ejes: la televisión como emprendedora de la memoria, como escenario de la memoria y como vebiculo de transmisión intergeneracional.

Pareciera ser que los mismos lenguajes del espectáculo televisivo que llevan a la identificación desde lo emocional, que ocluyen el desarrollo de aspectos complejos de la historia narrada y que dificultan la reflexión política, son los que permiten generar un público interesado, divulgar la existencia de los emprendimientos memoriales, legitimar algunas voces previamente silenciadas y, en términos más puntuales, producir una empatía hacia la temática por parte de las generaciones más jóvenes.

Sin embargo, al colocar determinados acontecimientos del pasado como problema público (Edelman, 1991), la televisión también puede ayudar a abrir una "ventana de oportunidad" para actores ya concernidos, y potenciar y articular, así, acciones que ciertos emprendedores de la memoria desarrollan aisladamente. Insisto en que no se puede mirar a la televisión solamente, sino 
todo el proceso memorial y los actores involucrados; pero tampoco puede desconocerse el enorme potencial que tiene la representación televisiva en los actuales procesos de construcción de memorias.

La producción del espectáculo televisivo puede ser, por lo tanto, también producción memorial. Pero, ¿qué tipo de memoria está ayudando a configurar este medio con su comunicación basada en imágenes y emociones?, ¿cuál es la relación entre televisión, memoria y política?, ¿de qué modos contribuye la TV al complejo proceso de memoria que sirve a las sociedades para elaborar sus experiencias traumáticas? Estos son algunos interrogantes que arroja la experiencia sobre el uso de la televisión en la Argentina, especialmente en los años posteriores a 1995, y que deberían ser incluidos en una agenda más completa de investigaciones tendiente a complejizar la categoría de memoria social, asignando importancia a los diversos modos en que ésta se articula con los medios masivos de comunicación.

\section{TELEVISION AS REGARDS THE RECENT PAST. HOW TO STUDY THE LINK BETWEEN TV AND SOCIAL MEMORY?}

Abstract: This article aims to examine the ways in which television represents Argentina's recent past, through three specific links between TV and social memory. Three approaches for research are proposed, which are different in analytical terms. These approaches allow us to focus on the role this medium plays in configuring public agendas (that is, television is approached as an entrepreneur of memory); its effectiveness as a medium which communicates past events to new generations (i.e., as a vehicle of transmission among generations); or its role as a constructor of meanings through images, sounds, and words (that is to say, television is approached as a stage for memory). All of these roles co-exist and are intertwined, but there is also tension among them. This article especially focuses on the experience of state terrorism in Argentina, in the framework of the military dictatorship in 1976-1983, as well as on the constructed memories about the disappearance of persons. The analysis of the links between TV and memory allows us to think how the obstacles to narrate an extreme experience are combined, in complex and not easily intelligible ways, with the sale of a product and entertainment.

Keywords: Television. Memory. Image. Dictatorship. Repression. 


\section{Claudia Feld}

\section{Notas}

${ }^{1}$ La noción de experiencia límite o "expérience extrême" ha sido desarrollada por POLLAK y HEINICH (1986).

${ }^{2}$ Estas problemáticas se han desarrollado, entre muchos otros, en: FRIEDLANDER (ed.), 1992; KOCH, 1990; HUYSSEN, 2002; BAER, 2006.

${ }^{3}$ Ver, entre otros: INSDORF, 1985; KAES, 1989; ZELIZER, 1999.

${ }^{4}$ Uno de los trabajos más sistemáticos sobre esta problemática es el que comprende los doce libros de la colección "Memorias de la represión”, dirigida por Elizabeth Jelin y editada por Siglo XXI de España Editores entre 2002 y 2006, como resultado del programa de formación e investigación llevado a cabo por el Social Science Research Council (SSRC).

${ }^{5}$ La ESMA, ubicada en la ciudad de Buenos Aires, fue uno de los centros clandestinos de detención, tortura y exterminio más activos del período dictatorial. Se calcula que por allí pasaron 5.000 detenidos y sobrevivieron alrededor de 200 .

${ }^{6}$ Programa Hora Clave del 9 de marzo de 1995, presentado por Mariano Grondona, periodista católico y conservador, ligado a pasados regímenes militares, pero que en los años '90 trató de distanciarse de ese pasado mediante una postura de defensa de las instituciones democráticas.

${ }^{7}$ Después de someter a los secuestrados a torturas físicas y psicológicas, los militares eliminaban a los detenidos arrojándolos al mar, adormecidos, desde aviones en vuelo, o los ejecutaban y luego ocultaban sus cuerpos quemándolos o enterrándolos en fosas comunes (ver CONADEP, 1984, p. 235-237). Las declaraciones de Scilingo que fueron televisadas habían sido grabadas un día antes y se presentaban como una continuación del programa de la semana anterior, en donde Grondona había invitado al periodista Horacio Verbtisky, autor del libro El V uelo (VERBITSKY, 1995), basado en una larga entrevista a Scilingo.

${ }^{8}$ Es necesario aclarar que las declaraciones de Scilingo no se dieron en el vacío. Coincidieron con acciones que, desde hacía tiempo, estaban llevando a cabo en Argentina las organizaciones de derechos humanos, con una distancia temporal de casi veinte años respecto del golpe de Estado de 1976, y con una nueva generación de jóvenes que empezó a impulsar cuestiones relativas a la memoria. Para una descripción de tales acciones durante ese período, ver VALDEZ, 2001, p. 63-82. ${ }^{9}$ En la manifestación del 24 de marzo de 1995, "nuevos actores sociales comienzan a participar de las conmemoraciones, mediante multitud de pequeños actos e iniciativas, algunas particulares pero otras provenientes de instituciones 
públicas" (LORENZ, 2002, p. 21). Los actos de conmemoración cobraron una mayor envergadura en 1996, para el vigésimo aniversario del golpe de Estado.

${ }^{10}$ Las grietas en la impunidad que se abrieron a mediados de los ' 90 se profundizaron en la Argentina en un contexto político muy diferente, algunos años después, con la asunción del presidente Néstor Kirchner. En 2003 el Congreso anuló por inconstitucionales las leyes de "Obediencia Debida" y "Punto Final" y pudieron reabrirse muchos de los juicios cerrados en 1987. Actualmente, cientos de represores están siendo juzgados en diversos tribunales de la Argentina y muchos ya fueron condenados. Para más información sobre el desarrollo de estos juicios, ver http://www.cels.org.ar/wpblogs/. Acesso em: 19 jun. 2012.

${ }^{11}$ Miniserie televisiva realizada en 1978, que contaba los avatares de una familia judía durante el Nazismo. Fue dirigida por Marvin Chomsky y emitida por la cadena norteamericana NBC.

${ }^{12}$ La noción de "emprendedor de la memoria" hace referencia a aquellas personas o grupos de personas "que pretenden el reconocimiento social y de legitimidad política de una (su) versión o narrativa del pasado. Y que también se ocupan y preocupan por mantener visible y activa la atención social y política sobre su emprendimiento" (JELIN, 2002, p. 49. Enfatizado por la autora).

${ }^{13}$ Cuando nos referimos a la TV como "institución", estamos considerando los múltiples niveles de la enunciación que presenta la televisión, porque en ellos encontramos agentes distintos. De un modo muy general, podemos decir que en la televisión (estamos considerando, sobre todo, los programas de géneros informativos de la televisión argentina) el lugar de enunciación se sitúa en una pluralidad de voces o de niveles en los que están involucrados el medio, los productores, los presentadores y los protagonistas de los hechos. Estas instancias, de acuerdo con diversas variables (el canal, el momento político, el tipo de información, entre otras) actúan con diferente peso y poder de decisión.

${ }^{14}$ Nuestro análisis de los "escenarios de la memoria" da cuenta, al menos, de tres dimensiones: una dimensión narrativa (el contar una historia), en la que importa el tipo de relato que se construye y las claves en que se narra la historia; una dimensión espectacular (una puesta en escena), en la que importan los lenguajes y los elementos usados en la escenificación; y una dimensión veritativa (un trabajo de producción de una verdad) en la que importa qué tipo de verdad sobre el pasado se construye y en lucha con qué otras verdades.

${ }^{15}$ Tal como lo expresa Anton Kaes, este dilema puede definirse de la siguiente manera: "Si se acepta que la catastrófica destrucción masiva que tuvo lugar hace cincuenta años desafía no solo la descripción histórica y la determinación cuantitativa sino también la explicación racional y la articulación lingüística, entonces se requiere una nueva manera autorreflexiva de codificar la historia" (KAES, 1992, p. 208). 


\section{Claudia Feld}

${ }^{16}$ Por ejemplo, en Francia las representaciones de la deportación que accedieron al espacio público en los años inmediatamente posteriores a la Segunda Guerra se centraron, casi exclusivamente, en la figura del resistente, dejando de lado la figura del deportado "por razones raciales", es decir, no dando cuenta de la singularidad del genocidio. En parte, esto se explica porque políticamente convenía construir un tipo de memoria que sirviera para la reunificación de Francia, es decir, una memoria heroica de lo sucedido durante la ocupación. Ver, entre otros: ROUSSO, 1987; WIEVIORKA, 1992.

${ }^{17}$ Debo aclarar aquí que estas consideraciones se refieren particularmente a la televisión argentina, que ha sido principalmente privada y comercial, sobre todo en la etapa que se analiza en este trabajo (es decir, entre mediados de los años 90 y principios de los 2000).

${ }^{18}$ Incluimos aquí solo algunas observaciones. Para un mayor desarrollo de algunas de ellas, ver FELD, 2006 y FELD, 2009a. Los géneros informativos de la televisión argentina han prevalecido sobre los ficcionales en la representación de esta temática: recién en los primeros años 2000 comenzaron a producirse ficciones y telenovelas que abordaban la cuestión de los desaparecidos y, especialmente, la de los niños apropiados ilegalmente.

${ }^{19}$ Tal como lo explica Michèle Lagny para la imagen fílmica: "En el flujo de las imágenes, la última representación borra las precedentes: la reproducción fílmica no obedece a una lógica de acumulación sino a la del pasaje; esto no es solamente una consecuencia del flujo de la imagen-film, sino su principio mismo" (LAGNY, 1991, p. 72).

${ }^{20}$ Realicé dos entrevistas en profundidad a cada uno de los 10 entrevistados/as (5 hombres, 5 mujeres). La primera entrevista fue una "historia de vida" que tomó como eje central la relación de esa persona con el tema de la represión dictatorial: qué recuerdos tiene, qué cree que le afectó más, qué opina, los canales por los cuales obtuvo información. En una segunda parte de esa primera entrevista, se puso el acento en la relación entre estas memorias y el contacto que los entrevistados/as han tenido con materiales audiovisuales que evocan el tema de la represión, ya sea en el pasado o en los últimos años. La segunda entrevista, también individual, tuvo como punto de partida la proyección de un programa televisivo. El programa elegido fue "ESMA: El día del juicio" (emitido por Canal 13, en agosto de 1998). El trabajo de investigación fue financiado con una beca doctoral del Instituto de Desarrollo Económico y Social (IDES).

${ }^{21}$ Los nombres están cambiados, en función de mantener reserva sobre la identidad de los entrevistados/as.

${ }^{22}$ Entre los que han tenido mayor repercusión y se conocen más ampliamente, podemos mencionar la película "La noche de los lápices" (OLIVERA, Héctor, 1986) y el prólogo del Informe Nunca Más (CONADEP, 1984). Si bien la visión 
de los desaparecidos como militantes comenzó a hacerse presente en libros y películas desde 1996, llegó a la televisión mucho después, en la etapa posterior a 2003, después de la asunción de Néstor Kirchner como presidente, en el marco de una política y un discurso gubernamental que exaltaba la militancia y los actores políticos de los años '70, considerándolos como una generación de lucha. ${ }^{23}$ Por ejemplo, la película Garage Olimpo (Marco Bechis, 1999).

${ }^{24}$ En la televisión, las palabras de estos represores se ilustraron con imágenes "reconstituidas" de tomas aéreas sobre el mar, de aviones militares en vuelo, o de sombras de aviones militares sobre un espejo de agua. Esas imágenes se siguieron utilizando, no solo en televisión sino también en cine, no solo en géneros informativos sino también en ficción.

\section{Referências}

BAER, Alejandro. Holocausto: Recuerdo y representación. Madrid: Losada, 2006. CALVEIRO, Pilar. Poder y desaparición: Los campos de concentración en Argentina. Buenos Aires: Colihue, 1998.

CARUTH, Cathy. Unclaimed experience: Trauma, Narrative, and History. Maryland: The Johns Hopkins University Press, 1996.

CONADEP. Nunca Más: Informe de la Comisión nacional sobre la desaparición de personas. Buenos Aires: Eudeba, 1984.

EDELMAN, Murray. La construcción del espectáculo político. Buenos Aires: Manantial, 1991.

FELD, Claudia. "Quand la television argentine convoque les disparus. Modalités et enjeux de la représentation médiatique d'une expérience extrême". Les temps des médias, París, n. 6, Printemps 2006.

. "Aquellos ojos que contemplaron el límite: La puesta en escena televisiva de testimonios sobre la desaparición". In: FELD, Claudia y STITES MOR, Jessica (comps.), Elpasado que miramos: Memoria e imagen ante la historia reciente. Buenos Aires: Paidós. 2009a.

. Entre la visibilidad y la justicia: los testimonios televisivos de represores en la Argentina, Encuentros Uruguayos, Montevideo: Año II, n. 2, noviembre 2009b. FRIEDLANDER, Saul (ed.). Probing the Limits of Representation. Nazism and the "Final Solution". Cambridge / London: Harvard University Press, 1992.

HALBWACHS, Maurice. La memoria colectiva. Zaragoza: Prensas Universitarias de Zaragoza, 2004 [1950]. 


\section{Claudia Feld}

HUYSSEN, Andreas. En busca del futuro perdido: Cultura y memoria en tiempos de globalización. México: Fondo de Cultura Económica, 2002.

INSDORF, Annette. L'Holocauste à l'écran, Cinémaction, París, n. 32, 1985.

JELIN, Elizabeth. Los trabajos de la memoria. Madrid y Buenos Aires: Siglo Veintiuno Editores, 2002.

KAES, Anton. Holocaust and the End of History: Postmodern Historiography in Cinema. In: FRIEDLANDER, Saul (ed) Probing the Limits of Representation. Nazism and the "Final Solution". Cambridge / London: Harvard University Press, 1992.

$\mathrm{KOCH}$, Gertrude, Transformations esthétiques dans la représentation de l'inimaginable. In: VVAA, Au sujet de Shoah. Le film de Claude Lanzmann. Paris: Belin, 1990.

LACAPRA, Dominick. Historia y memoria después de Auschwitz. Buenos Aires: Prometeo, 2009.

LAGNY, Michèle. L'histoire contre l'image, l'image contre la mémoire. In : Hors Cadre (Le cinéma à travers champs disciplinaires), París, n. 9, Printemps, 1991.

LORENZ, Federico. ¿De quién es el 24 de marzo? Las luchas por la memoria del golpe de 1976. In: JELIN, Elizabeth (comp.). Las conmemoraciones: Las disputas en las fechas "in-felices". Madrid y Buenos Aires: Siglo Veintuno Editores, 2002. NORA, Pierre (dir.) (1984-1992). Les lieux de mémoire, París, Gallimard, 3 tomos. POLLAK, Michael. L'expérience concentrationnaire. Essai sur le maintien de l'identité sociale. París: Editions Métailié, 1990.

Une identité blessée: études de sociologie et d'histoire. París: Editions Métailié, 1993.

. y HEINICH, Nathalie. Le témoignage, Actes de la recherche en sciences sociales, París, n. 62-63, junio 1986.

RICOEUR, Paul. La lectura del tiempo pasado: memoria y olvido. Madrid: Ediciones UAM, 1999.

. La mémoire, l'histoire, l'oubli. Paris: Seuil, 2000.

ROUSSO, Henry. Le syndrome de Vichy, de 1944 à nos jours. Paris: Seuil, 1987.

SHANDLER, Jeffrey (1999) While America Watches. Televising the Holocaust. New York, Oxford: Oxford Univsity Press.

TODOROV, Tzvetan. Les abus de la mémoire. París: Arléa, 1995.

VALDEZ, Patricia. Tiempo óptimo para la memoria. In Groppo, Bruno y Flier, Patricia (comps.). La imposibilidad del olvido. Recorridos de la memoria en Argentina, Chile y Uruguay. La Plata: Ediciones Al Margen, 2001. 
La televisión ante el pasado reciente:...

VERBITSKY, Horacio. El Vuelo. Buenos Aires: Planeta, 1995.

VERON, Eliseo. Il est là, je le vois, il me parle. Communications, París: n. 38, 1983.

WIEVIORKA, Annette. Déportation et génocide. Entre la mémoire et l'oubli. Paris: Plon, 1992.

ZELIZER, Barbie (ed). Visual Culture and the Holocaust. New Brunswick, New Jersey: Rutgers University Press, 1999.

Recebido em 19/07/2012

Aprovado em: 10/09/2012 